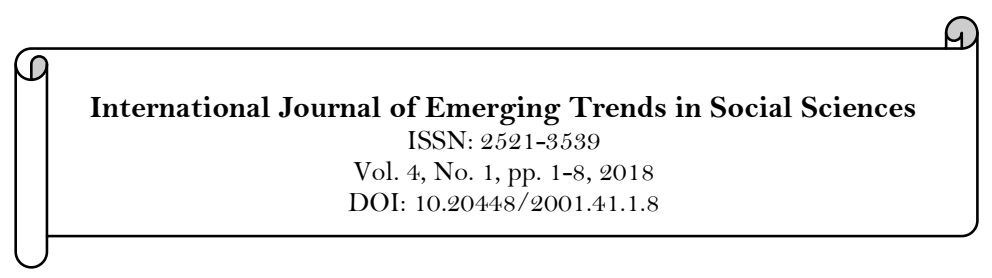

\title{
Basic Literacy and Attainment of Good Health and Well-Being among Young Adults in Ekiti State, Nigeria
}

\author{
Olusegun O. Owolewa ${ }^{12}$ \\ Omolola F. Adepoju ${ }^{2}$ \\ 1,2Department of Arts Education, Adekunle Ajasin University, Akungba Akoko, Ondo State, Nigeria. \\ ${ }^{1}$ Email:olusegun.owolewa@aaua.edu.ng
}

\begin{abstract}
Eradication of poverty and shifting the world onto a sustainable and resilient development pathway are part of the many agenda set at different times in history of the world by the United Nations. The realisation of these agenda is largely presumed to rest on literacy level of the world. Most health challenges in the nation have proven difficult to control or handle because the level of health literacy amongst Nigerians appears inadequate in the aspects that directly impact their health. The main purpose of this study was to establish the link between Sustainable Development Goals (SDGs) 3 and basic literacy, and determine, both quantitatively and qualitatively, how it affects the achievement of SDG 3 among young adults. A naturalistic inquiry was adopted to obtain data among the targeted population; questionnaire was formulated to answer the set research questions; 250 respondents within ages 18 to 35 were targeted, 125 each from selected LGA. Results of the study showed that basic/health literacy has significant influence on the health perception of the population. The study further shows that health performance is a function of health literacy and indirect function of level of education. This study recommended that government at all levels should embark on serious awareness campaign to intimate all Nigerians with SDGs and incorporate health programmes and awareness as a compulsory aspect of education at all levels.
\end{abstract}

\author{
Keywords: \\ Basic literacy \\ Health performance \\ Education for all \\ Health awareness. \\ Licensed: \\ This work is licensed under a \\ Creative Commons Attribution \\ 4.0 License. \\ Publisher: \\ Scientific Publishing Institute
}

\section{Introduction}

History of development in nations of the world has always included setting up developmental goals, which are subsequently followed systematically to achieve development. In September 2015, United Nations (UN) adopted a new comprehensive, ambitious, and transformational development agenda. The Outcome Document adopted during the summit outlines a set of 17 Sustainable Development Goals (SDGs) and 169 targets aimed at eradicating poverty in all its forms and shifting the world onto a sustainable and resilient development pathway while ensuring that "no one is left behind. Strikingly, the jump from the MDGs to the SDGs is not simply a question of extending the timeline and the ambition of the goals. New goals have been added, entirely new sectors have been introduced, and the number of indicators has more than doubled. The breadth and depth of the endeavour will now involve a substantial multiplication of activities and an expansion of partnerships and institutions. Moreover, a number of the SDGs do not simply specify outcome goals, but also the means by which these goals should be achieved.

SDG 3 aims at attaining healthy life for all at all ages.. To achieve these targets, it is important to understand the impact of Health Safety and Environment (HSE) literacy (education) within targeted population, as it greatly impacts the success of SDG 3.

"Health is wealth" is a common saying. The key to progressive development in a country is good health of its citizens. "SDG 3", part of the UN's 17 developmental goal, focuses on achieving the attainment of healthy life for all at all ages; this goal has set targets and with four of the targets as means of implementation, the SDG 3 targets can summarily be referred to as "Health Safety and Environment (HSE-)." The SDG 3 incorporates targets that involve health of the people, safety of the people and achieving a clean environment; these all will foster good health of the people. 
As documented by the Voluntary National Reviews on the implementation of the 2030 agenda (2017) reported that in Nigeria, high disease burden (Malaria, HIV, Polio and others.) amongst other factors has been responsible for non-translation of past growth into tangible development; the recent being the "achieving less to the fore-planned development" through the MDGs programmes. Basic literacy has significant effect on health; literacy level may contribute significantly to the health status of an individual or a group of people. Many women in rural communities do not possess basic literacy skills such as the ability to read, write, or count. These skills are needed for the purpose of understanding prescriptions and/or instructions given by health workers or doctors and in accessing health tips or useful information regarding health. Most health challenges in the nation has proven difficult to control or handle because the level of health literacy amongst Nigerians is inadequate in the aspects that directly impact their health such as: Health Safety and Environment (HSE), Environmental Impact Assessment/Auditing (EIA), Road/Traffic laws, Nutrition/personal Hygiene etc. this has made it hard to achieve the health goals set in time past and may as well affect any set health goal in the future. Therefore, this study investigated the link between successful translation of SDG 3 into growth and development.

For the purpose of this study, the following research questions were set.

1. What are the parameters that determine or affect basic health literacy in youths and young adults?

2. What effect does the level of education have on basic health literacy in young adults?

3. What is the level of basic health literacy in young adults of Emure/Ise-Orun LGA?

4. Is there variation in the health performance of young adults based on their basic health literacy?

The following hypotheses were asked:

i. $\quad$ Basic health literacy has no significant influence on health perception among young adults

ii. There are no significant differences in the awareness of basic health literacy of male young adults compared to female young adults.

iii. Age will have no significant influence on the awareness of basic health literacy among young adults.

iv. Marital status will have no significant influence on the awareness of basic health literacy among young adults.

\section{Method}

A sample size is used to represent the total population. The sample size for this research work is two hundred and fifty respondents, one hundred and twenty-five from each adopted LGA (Emure/Ise Local Government Area). 125 participants were randomly selected from each Local Government area of Ekiti State to complete the instruments. The study area covered two local governments in Ekiti South Senatorial district: Emure LGA and ISE-Orun LGA of Ekiti State, The adapted instrument is a questionnaire structured to answer the research questions and test the set hypotheses. The evidence of reliability of the test instrument is provided by making use of test-retest procedure.

All returned survey questionnaire were coded and analysed using IBM SPSS Statistics (Version 20), frequency distribution and inferential statistics were adopted.

\section{Results}

The result shows that $48.4 \%$ of the respondents were male, while $51.6 \%$ were female; respondents' age distribution shows that $29.2 \%$ of the respondents were within the age grouping of 18 and 22 years, $44 \%$ were within the age grouping of 23 and 27 years, $20.4 \%$ were within the age grouping of 28 and 32 years, while $6.4 \%$ were 33 years of age and above. The respondents' marital statuses reveals that $59.2 \%$ were single, $34.8 \%$ were married, $4 \%$ were divorced, while $2 \%$ were widowed. On the bases of religion, it was observed that $58.8 \%$ of the respondents were Christians, 36\% were Muslims, while $5.2 \%$ were involved with the traditional form of religion. The level of education level of education of the respondents varies, $20 \%$ of the respondents attained primary school education level, $37.2 \%$ were educated to secondary school level, and $37.6 \%$ had tertiary form of education, while $5.2 \%$ had no formal education. Summary of result of tested demographic features are presented on Table 1. 
Table-1. Summary of the demographic features of respondents.

\begin{tabular}{|c|c|c|c|c|c|c|c|c|c|c|c|c|c|c|}
\hline \multicolumn{3}{|c|}{ Gender Distribution } & \multicolumn{3}{|c|}{ Age Distribution } & \multicolumn{3}{|c|}{ Marital Status } & \multicolumn{3}{|l|}{ Religion } & \multicolumn{3}{|c|}{ Educational Status } \\
\hline Gender & $\begin{array}{l}\text { Freque } \\
\text { ncy }\end{array}$ & $\%$ & Age & Frequency & $\%$ & $\begin{array}{l}\text { Marital } \\
\text { Status }\end{array}$ & Frequency & $\%$ & Religion & $\begin{array}{l}\text { Frequ } \\
\text { ency }\end{array}$ & $\%$ & $\begin{array}{l}\text { Educational } \\
\text { Status }\end{array}$ & Frequency & $\%$ \\
\hline Male & 121 & 48.4 & $18-22 y r s$ & 73 & 29.2 & Single & 148 & 59.2 & $\begin{array}{l}\text { Christian } \\
\text { ity }\end{array}$ & 147 & 58.8 & $\begin{array}{l}\text { Primary } \\
\text { School }\end{array}$ & 50 & 20.0 \\
\hline Female & 129 & 51.6 & $23-27 \mathrm{yrs}$ & 110 & 44.0 & Married & 87 & 34.8 & Islam & 90 & 36.0 & $\begin{array}{l}\text { Secondary } \\
\text { School }\end{array}$ & 93 & 37.2 \\
\hline \multirow[t]{3}{*}{ Total } & 250 & 100.0 & $28-32$ yrs & 51 & 20.4 & Divorced & 10 & 4.0 & $\begin{array}{l}\text { Tradition } \\
\text { al }\end{array}$ & 13 & 5.2 & $\begin{array}{l}\text { Tertiary } \\
\text { Institution }\end{array}$ & 94 & 37.6 \\
\hline & & & $\begin{array}{l}33 \text { yrs and } \\
\text { above }\end{array}$ & 16 & 6.4 & Widowed & 5 & 2.0 & Total & 250 & 100.0 & None & 13 & 5.2 \\
\hline & & & Total & 250 & 100.0 & Total & 250 & 100.0 & & & & Total & 250 & 100.0 \\
\hline
\end{tabular}

Source: Field Survey. 
Research Question 1: What are the parameters that determine or affect basic health literacy among young adults?

Table-2. Chi Square summary on statement regarding the parameters that determine basic health literacy among young adults.

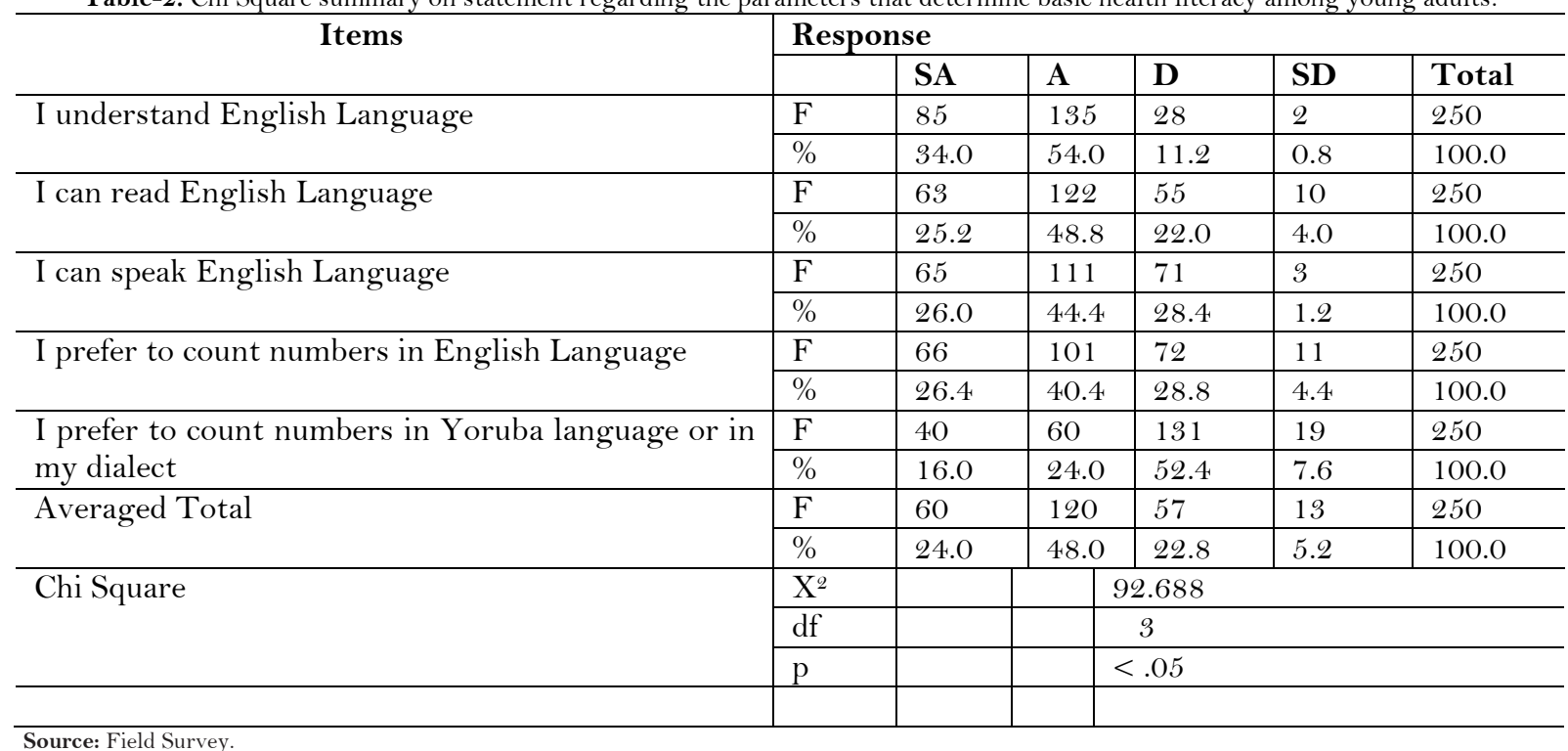

The result on Table 2 shows that $88 \%$ of the respondents understand English Language and $12 \%$ do not. Out of the whole population, $74 \%$ of the respondents possess basic reading literacy skill in English Language, while $26 \%$ do not. In a similar trend, $70.4 \%$ of the respondents possess basic speaking literacy skill in English Language, while $29.6 \%$ do not. $66.8 \%$ of the respondents possess basic counting/numeracy literacy skill in English Language, while $33.2 \%$ do not. Despite the numeracy skill possess by the larger percentage of the population, $40 \%$ of the respondents opined that they prefer to count numbers in Yoruba language or in their dialect, while majority $(60 \%)$ negated it. This implies that most of the respondents prefer English Language, thus making it strong parameters that determine or affect basic health literacy among young adults.

Probability p value for the tested hypothesis is less than 0.05 level of significant, which implied that the observed differences in the response is valid for conclusion

Research Question 2: What effect does the level of education have on basic health literacy in young adults?

Table-3. Chi Square summary on statement regarding the effect of education level on basic health literacy among young adults.

\begin{tabular}{|c|c|c|c|c|c|c|}
\hline \multirow[t]{2}{*}{ Items } & \multicolumn{6}{|c|}{ Response } \\
\hline & & $\mathbf{S A}$ & A & D & SD & Total \\
\hline \multirow{2}{*}{$\begin{array}{l}\text { I prefer listening to or watching health } \\
\text { programmes in English }\end{array}$} & $\mathrm{F}$ & 74 & 9 & 108 & 59 & 250 \\
\hline & $\%$ & 29.6 & 3.6 & 43.2 & 23.6 & 100.0 \\
\hline \multirow{2}{*}{$\begin{array}{l}\text { I prefer listening to or watching health } \\
\text { programmes in Yoruba or in my dialect }\end{array}$} & $\mathrm{F}$ & 71 & 84 & 88 & 7 & 250 \\
\hline & $\%$ & 28.4 & 33.6 & 35.2 & 2.8 & 100.0 \\
\hline \multirow{2}{*}{$\begin{array}{l}\text { I prefer traditional health system to orthodox } \\
\text { health system because it is more affordable }\end{array}$} & $\mathrm{F}$ & 18 & 76 & 98 & 58 & 250 \\
\hline & $\%$ & 7.2 & 30.4 & 39.2 & 23.2 & 100.0 \\
\hline \multirow{2}{*}{$\begin{array}{l}\text { I prefer modern health system to traditional } \\
\text { health system because it is affordable }\end{array}$} & $\mathrm{F}$ & 66 & 89 & 78 & 17 & 250 \\
\hline & $\%$ & 26.4 & 35.6 & 31.2 & 6.8 & 100.0 \\
\hline \multirow{2}{*}{$\begin{array}{l}\text { Doctors' prescriptions are not always readily } \\
\text { available in store, so I buy related medication }\end{array}$} & $\mathrm{F}$ & 9 & 31 & 109 & 101 & 250 \\
\hline & $\%$ & 3.6 & 12.4 & 43.6 & 40.4 & 100.0 \\
\hline \multirow[t]{2}{*}{ Averaged Total } & $\mathrm{F}$ & 61 & 79 & 75 & 35 & 250 \\
\hline & $\%$ & 24.4 & 31.6 & 30.0 & 14.0 & 100.0 \\
\hline \multirow[t]{3}{*}{ Chi Square } & $\mathrm{X}^{2}$ & & \multicolumn{4}{|c|}{\begin{tabular}{c|c} 
& 18.992 \\
\end{tabular}} \\
\hline & $\mathrm{df}$ & & \multicolumn{4}{|c|}{3} \\
\hline & $\mathrm{p}$ & & \multicolumn{4}{|c|}{$<.05$} \\
\hline
\end{tabular}

Source: Field Survey.

The result on Table 3 indicates that $33.2 \%$ of the respondents are in support of the statement that they prefer listening to or watching health programmes in English, while $66.8 \%$ said otherwise. In a similar trend, it was also observed that $62 \%$ of the respondents supported the statement that said they prefer listening to or watching health programmes in Yoruba or in my dialect, while 38\% said otherwise. This implied that the respondents enjoy listening to events more in Yoruba languages. It was observed that $37.6 \%$ of the 
respondents supported the statement that said they prefer traditional health system to orthodox health system because it is more affordable, while $62.4 \%$ said otherwise. In a confirmatory statement, it was opined that $62 \%$ of the respondents affirmed the statement that they prefer modern health system to traditional health system because it is affordable, while $38 \%$ did not. Lastly, it was noted that majority of the respondents ( $84 \%)$ negated the statement that said doctors' prescriptions are not always readily available in store, so I buy related medication, while $16 \%$ said otherwise. $56 \%$ of the respondents agreed that the type of language and education that an individual prefer and attain respectively will determine their basic health literacy. This was further confirmed with the chi square results $\left(\mathrm{X}^{2}=18.992, \mathrm{df}=3, \mathrm{p}<.05\right)$.

Research Question 3: What is the level of basic/health literacy in young adults of Emure/Ise-Orun LGA?

Table-4. Chi Square summary on statement regarding the level of basic health literacy among youths and young adults of Emure and IseOrun LGA.

\begin{tabular}{|c|c|c|c|c|c|c|}
\hline \multirow[t]{2}{*}{ Items } & \multicolumn{6}{|c|}{ Response } \\
\hline & & $\mathbf{S A}$ & $\mathbf{A}$ & D & SD & Total \\
\hline \multirow[t]{2}{*}{ I am aware of Sustainable Development Goals } & $\mathrm{F}$ & 54 & 79 & 100 & 17 & 250 \\
\hline & $\%$ & 21.6 & 31.6 & 40.0 & 6.8 & 100.0 \\
\hline \multirow{2}{*}{$\begin{array}{l}\text { I am aware that immunization is good and it helps to fight } \\
\text { against diseases both in adult and children }\end{array}$} & $\mathrm{F}$ & 84 & 137 & 22 & 7 & 250 \\
\hline & $\%$ & 33.6 & 54.8 & 8.8 & 2.8 & 100.0 \\
\hline \multirow{2}{*}{$\begin{array}{l}\text { I am aware of epidemics outbreaks, terminal diseases and } \\
\text { other forms of communicable diseases and how to manage } \\
\text { them }\end{array}$} & $\mathrm{F}$ & 59 & 142 & 39 & 10 & 250 \\
\hline & $\%$ & 23.6 & 56.8 & 15.6 & 4.0 & 100.0 \\
\hline \multirow{2}{*}{$\begin{array}{l}\text { Doctors' prescriptions are the best and they are always } \\
\text { accurate }\end{array}$} & $\mathrm{F}$ & 36 & 140 & 57 & 17 & 250 \\
\hline & $\%$ & 14.4 & 56.0 & 22.8 & 6.8 & 100.0 \\
\hline \multirow{2}{*}{$\begin{array}{l}\text { I don't need doctors' prescriptions to take medications, since I } \\
\text { can take care of myself }\end{array}$} & $\mathrm{F}$ & 35 & 47 & 122 & 46 & 250 \\
\hline & $\%$ & 14.0 & 18.8 & 48.8 & 18.4 & 100.0 \\
\hline \multirow[t]{2}{*}{ Averaged Total } & $\mathrm{F}$ & 56 & 124 & 53 & 17 & 250 \\
\hline & $\%$ & 22.4 & 49.6 & 21.2 & 6.8 & 100.0 \\
\hline \multirow[t]{3}{*}{ Chi Square } & $\mathrm{X}^{2}$ & & & \multicolumn{3}{|c|}{95.760} \\
\hline & $\mathrm{df}$ & & & \multicolumn{3}{|c|}{3} \\
\hline & $\mathrm{p}$ & & & \multicolumn{3}{|c|}{$<.05$} \\
\hline
\end{tabular}

Result summarised on Table 4 reveals that most of the respondents (53.2\%) support the statement that they are aware of Sustainable Development Goals, while $46.8 \%$ do not. Also, most of the respondents $88.4 \%$ they are aware that immunization is good and it helps to fight against diseases both in adult and children, while just $11.6 \%$ said otherwise. Majority of the respondents (80.4\%) also confirmed the statement that they are aware of epidemics outbreaks, terminal diseases and other forms of communicable diseases and how to manage them, while $19.6 \%$ do not. It was noted that most of the respondents $(70.4 \%)$ affirmed the statement that doctors' prescriptions are the best and they are always accurate, while $29.6 \%$ do not. Majority of the respondents $(67.2 \%)$ do not support the statement that said "I do not need doctors' prescriptions to take medications, since I can take care of myself”, while 32.8\% supported. The average summary indicates that $72 \%$ of the respondents possess knowledge of basic health literacy among youths and young adults of Emure and Ise-Orun LGA, while $28 \%$ do not. With the $\mathrm{X}^{2}$ value of 95.760 , $\mathrm{df}$ of 3 and p value less than 0.05 level of significant, the observed differences in the response was valid for conclusion.

Research Question 4: Is there variation in the health performance of young adult based on their basic health literacy?

Table-5. Chi Square summary on statement regarding variation in the health performance of young adult based on their basic health literacy.

\begin{tabular}{|c|c|c|c|c|c|c|}
\hline \multirow[t]{2}{*}{ Items } & \multicolumn{6}{|c|}{ Response } \\
\hline & & $\mathbf{S A}$ & A & D & SD & Total \\
\hline \multirow{2}{*}{$\begin{array}{l}\text { I don't need doctors and health facilities } \\
\text { since there are traditional medicines and } \\
\text { herbs }\end{array}$} & $\mathrm{F}$ & 48 & 48 & 114 & 40 & 250 \\
\hline & $\%$ & 19.2 & 19.2 & 45.6 & 16.0 & 100.0 \\
\hline \multirow{2}{*}{$\begin{array}{l}\text { Modern medicines don't work well or are } \\
\text { not effective like the traditional medicines }\end{array}$} & $\mathrm{F}$ & 29 & 72 & 118 & 31 & 250 \\
\hline & $\%$ & 11.6 & 28.8 & 47.2 & 12.4 & 100.0 \\
\hline \multirow{2}{*}{$\begin{array}{l}\text { Modern medicines are too expensive and not } \\
\text { available except in the hospitals }\end{array}$} & $\mathrm{F}$ & 20 & 71 & 112 & 47 & 250 \\
\hline & $\%$ & 8.0 & 28.4 & 44.8 & 18.8 & 100.0 \\
\hline \multirow{2}{*}{$\begin{array}{l}\text { Visiting the hospital can stigmatize me in } \\
\text { the society }\end{array}$} & $\mathrm{F}$ & 24 & 52 & 116 & 58 & 250 \\
\hline & $\%$ & 9.6 & 20.8 & 46.4 & 23.2 & 100.0 \\
\hline \multirow{2}{*}{$\begin{array}{l}\text { Hospitals are for those with deadly or } \\
\text { terminal disease }\end{array}$} & $\mathrm{F}$ & 21 & 51 & 76 & 102 & 250 \\
\hline & $\%$ & 8.4 & 20.4 & 30.4 & 40.8 & 100.0 \\
\hline \multirow[t]{2}{*}{ Averaged Total } & $\mathrm{F}$ & 28 & 59 & 107 & 56 & 250 \\
\hline & $\%$ & 11.2 & 23.6 & 42.8 & 22.4 & 100.0 \\
\hline
\end{tabular}

Source: Field Survey. 
Considering the items on variation in the health performance of young adult based on their basic health literacy, the result on Table 5 shows that most of the respondents $(61.6 \%)$ negated the statement that they do not need doctors and health facilities since there are traditional medicines and herbs, while $38.4 \%$ supported it. This implies that majority prefer doctors and health facilities to traditional. The result also shows that most of the respondents $(59.6 \%)$ negated the statement that says "modern medicines don't work well or are not effective like the traditional medicines", while 40.4\% agrees otherwise. Majority (63.6\%) negated the statement that "modern medicines are too expensive and not available except in the hospitals", while 36.4\% supported it. Also, majority (69.6\%) supported the statement that "visiting the hospital can stigmatize me in the society", while $30.4 \%$ said otherwise; $71.2 \%$ of the respondents negated the statement that "hospitals are for those with deadly or terminal disease", while $28.8 \%$ said supported it.

The average summary revealed that majority of the respondents did not support the opinion that they had poor orientation and desire for modern medicines. This was such that $65.2 \%$ negated the view, while $34.8 \%$ supported it. The Chi square result further confirmed the non-significant variations in responses, thus the observed- majority confirmed that there was no significant variation in the health performance of young adult based on their basic health literacy $\left(\mathrm{X}^{2}=95.760, \mathrm{df}=3, \mathrm{p}<.05\right)$.

Hypothesis 1: Basic health literacy has no significant influence on health perception among young adult.

Table-6. Simple Regression showing the influence of basic health literacy on health perception among young adult.

\begin{tabular}{l|l|l|l|l|l|l|l}
\hline Variables & $\mathbf{B}$ & $\mathbf{T}$ & $\mathbf{P}$ & $\mathbf{R}$ & $\mathbf{R}^{\mathbf{2}}$ & $\mathbf{d f}$ & $\mathbf{F}$ \\
\hline $\begin{array}{l}\text { Awareness of Basic } \\
\text { /Health Literacy }\end{array}$ & .560 & $10.64^{*}$ & $<.05$ & .560 & .313 & 1,248 & $113.230^{* *}$ \\
\hline${ }^{* *} \mathrm{p}<0.01,{ }^{*} \mathrm{p}<0.05$. & & & & & & \\
\hline
\end{tabular}

The result also indicates that basic literacy had significant influence on health perception $(\beta=0.560$, $\mathrm{t}=10.64, \mathrm{p}<.05)$. This implied that the health perception of young adult is determined by their basic health literacy such that the higher their health/ basic literacy, the more positive they perceive modern health systems.

Hypothesis 2: There is no significant difference in the awareness of basic health literacy of male young adult compared to female young adult

The result reveals that gender had no significant difference in the awareness of basic health literacy $[\mathrm{t}(248)=0.576, \mathrm{p}>.05]$. This implied that young male adult $(\mathrm{M}=14.47 ; \mathrm{SD}=3.162)$ do not differ from their female counterparts $(\mathrm{M}=14.27 ; \mathrm{SD}=2.270)$ when compared on their level of awareness on basic health literacy.

Table-7. Independent T-test showing Gender difference on awareness of basic health literacy among young adult.

\begin{tabular}{l|l|l|l|l|l|l|l}
\hline & Gender & N & Mean & SD & df & t & p \\
\hline Basic Literacy & Male & 121 & 14.47 & 3.162 & 248 & .576 & $>.05$ \\
\cline { 2 - 5 } & Female & 129 & 14.27 & 2.270 & & & \\
\hline Source: Field Survey.
\end{tabular}

Hypothesis 3: Age will have no significant influence on the awareness of basic health literacy among young adult.

Table-8. One-Way ANOVA showing the Influence of age on awareness of basic health literacy among young adult.

\begin{tabular}{l|l|l|l|l|l}
\hline Source & SS & df & MS & F & p \\
\hline Between Groups & 45.023 & 3 & 15.008 & 2.032 & $>.05$ \\
\hline Within Groups & 1817.121 & 246 & 7.387 & & \\
\hline Total & 1862.144 & 249 & & & \\
\hline Source: Field Survey.
\end{tabular}

The result indicates that age had no significant influence on the awareness of basic health literacy among young adult $[\mathrm{F}(3,246)=2.032, \mathrm{p}>.05]$. This implies that the age of young adult do not determine their awareness level of basic health literacy.

Hypothesis 4: Marital Status will have no significant influence on the awareness of basic health literacy among young adult. 
Table-9. One-Way ANOVA showing the Influence of Marital Status on awareness of basic health literacy among young adult.

\begin{tabular}{l|l|l|l|l|l}
\hline Source & SS & df & MS & F & P \\
\hline Between Groups & 55.064 & 3 & 18.355 & 2.499 & $>.05$ \\
\hline Within Groups & 1807.080 & 246 & 7.346 & & \\
\hline Total & 1862.144 & 249 & & & \\
\hline Source: Field Survey.
\end{tabular}

Result shows that marital status had no significant influence on the awareness of basic health literacy among young adult $[\mathrm{F}(3,246)=2.499, \mathrm{p}>.05]$. This implies that the either married, single, divorced or widowed do not determine the awareness level of basic health literacy among young adults. The result shows that educational qualification had significant influence on awareness of basic health literacy $[\mathrm{F}(3,246)=39.541, \mathrm{p}<.05]$. This implied that the level of education that young adult attain will determine their awareness level of basic health literacy among young adult.

Hypothesis 5: Educational qualification will have no significant influence on the awareness of basic health literacy among young adult.

Table-10. One-Way ANOVA showing the Influence of Educational Qualification on awareness of basic health literacy among young adult.

\begin{tabular}{l|l|l|l|l|l}
\hline Source & SS & df & MS & F & p \\
\hline Between Groups & 605.813 & 3 & 201.938 & 39.541 & $<.05$ \\
\hline Within Groups & 1256.331 & 246 & 5.107 & & \\
\hline Total & 1862.144 & 249 & & & \\
\hline Source: Field Survey. & &
\end{tabular}

The result presented on Table 4.14 shows that educational qualification had significant influence on awareness of basic health literacy $[\mathrm{F}(3,246)=39.541, \mathrm{p}<.05]$. This implied that the level of education that young adult attain will determine their awareness level of basic health literacy among young adult. This negate the formulated null hypothesis 5 , thus, it was rejected. To have a better understanding of the educational level that has the most impact on awareness level of basic health literacy among young adult, mean, and standard deviation was conducted and presented in table below.

\section{Discussion}

The study shows that respondents' socio-economic characteristics, except for level of education, have no effect on both level of literacy and health outcome which agrees with the findings of Bush et al. (2010) who claimed varying socio-economic factors such as age, sex, ethnicity amongst others. Findings from the study shows that level of education is a main factor that determines or affect basic health literacy in young adults of Emure and Ise-Orun Local Government Areas. According to the Federal Ministry of Education of Nigeria, 2010 (Cited in Adekunle (2010)) Nigeria has 500 indigenous languages and dialects and English Language has been chosen as the official language of communication at all level. Understanding of English Language is therefore a determining factor to develop basic health literacy as it represents the language of health communication in Nigeria. The study shows that the understanding of English Language to a speaking, reading and numeracy level is the determining parameter to developing basic health literacy among the young adults in the study area.

The research shows that the larger population of the respondents is aware of the SDGs, immunization, epidemic outbreaks and prefer doctors' prescriptions; this attests to the moderately high literacy level of the respondents. This is in support of the findings of Florence and Bimbola (2008). The respondents have a lower population who are against orthodox health care and afraid of being stigmatized by visiting the hospital, this reflects the low population of those with low health literacy and consequently low health performance. This is in accordance with the findings of Berkman et al. (2011). Contrary to the hypothesis set, findings from this study show that basic health literacy has significant influence on health perception among young adults in the study area. This is in line with the findings of (Chen, Huang, Yang, \& Lew-Ting, 2014); Deniz, Ozer, and Songur (2018) also established a strong relationship between literacy level and health perception of patients. The findings from this study show that both male and female young adults possess basic health literacy with no significant variation, which tested the hypothesis to be true. This is in line with the report of the National Bureau of Statistics, in the National Literacy Survey carried out in 2010.

The study shows that age does not influence the level of awareness of basic health literacy of targeted population for this study. This is in line with the findings of Bush et al. (2010) also in line with and Manoj (2010) who claimed that age does not determine the level of health literacy The study shows that marital status does not influence the level of awareness of basic health literacy of targeted population for this study. This is in line with the findings of Bush et al. (2010). This study shows a strong significant influence of 
education on the awareness of basic health literacy among young adults of the study area. This is corroborated by the reviewed works of Organisation for Economic Co-Operation and Development (2006). The review clearly showed that education is a strong factor that influences the awareness of basic health literacy and consequently health performance among young adults. This also agreed to the works carried out by Olshansky et al. (2012).

\section{Conclusion}

Base on the findings of this study, there is a strong link between achieving SDG 3 and level of basic literacy among the targeted population. Quantitatively, the study proved that the higher the percentage of people with basic health literacy among the young adult population, the increased the probability of achieving SDG3 within the set time. Qualitatively, overall health awareness and performance of the young adult population within the study area proven to improve with increased level of literacy. The population basic health literacy has been found to be greatly determined by their level of education-n, people with high level of education have better health literacy and consequently, better health performance compared to people with low level of education.

\section{References}

Adekunle, A. A. (2010). Correlations of health behaviour practices among literate adults of South West, Nigeria. An African Symposium: An Online Journal of the Educational Research Network, 10(2), 26-38.

Berkman, S. L., Sheridan, K. E., Donahue, A. V., Karen, C. A., Holland, M. B., Kathleen, N., \& Meera, V. (2011). Health literacy interventions and outcomes: An updated systematic review (Prepared For: Agency for Healthcare Research and Quality, US Department of Health and Human Services) by Nancy D. AHRQ Publication No: 11E006.

Bush, R., Boyle, F., Ostinim, R. M., Ozolins, L., Brabant, M., \& Soto, E. (2010). Advancing health literacy through primary health care systems. Canberra: Australian Primary Health Care Research Institute.

Chen, G., Huang, C., Yang, Y., \& Lew-Ting, C. (2014). Patient perception of understanding health education and instructions has moderating effect on glycemic control. BMC Public Health, 14(1), 683.

Deniz, S. S., Ozer, O., \& Songur, C. (2018). Effect of health literacy on health perception: An application in individual at age 65 and older. Social Work Public Health, 33(2), 85-95.

Florence, F. A., \& Bimbola, K. O. (2008). Knowledge of HIV/AIDS and sexual behaviour among youths in South Western Nigeria. Humanity and Social Sciences Journal, 3(1), 81-88.

Manoj, K. P. (2010). Association between marital status and health: Examining the role of age and gender. Delhi, India: Institute of Economic Growth.

Olshansky, S. J., Antonucci, T., Berkman, L., Binstock, R. H., Boersch-Supan, A., Cacioppo, J. T., \& Goldman, D. P. (2012). Differences in life expectancy due to race and educational differences are widening, and many may not catch up. Health affairs, 31(8), 1803-1813. Available at: https://doi.org/10.1377/hlthaff.2011.0746.

Organisation for Economic Co-Operation and Development. (2006). Education at a glance: Publication of Organisation for Economic Co-operation and Development (OECD). 